\title{
Effect of the Harmonic Voltage Distortion on the Efficiency of a Compact Fluorescent Lamp
}

Esteban Rojas-Osorio; Andrés-Julián Saavedra-Montes; Carlos-

Andrés Ramos-Paja

Citation: E. Rojas-Osorio, A.-J. Saavedra-Montes, C.-A. Ramos-Paja, "Effect of the Harmonic Voltage Distortion on the Efficiency of a Compact Fluorescent Lamp," Revista Facultad de Ingeniería, vol. 29 (54), e11604, 2020.

\section{https://doi.org/10.19053/01211129.v29.n54.2020.11604}

Received: August 20, 2020; Accepted: October 28, 2020;

Published: October 29, 2020

Copyright: This is an open access article distributed under license $\underline{\mathrm{CC}}$

$\underline{B Y}$

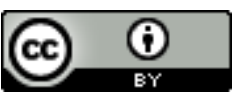

Conflict of interest: The authors state there is no conflict of interest. 


\title{
Effect of the Harmonic Voltage Distortion on the Efficiency of a Compact Fluorescent Lamp
}

\author{
Esteban Rojas-Osorio ${ }^{1}$ \\ Andrés Julián Saavedra-Montes² \\ Carlos Andrés Ramos-Paja ${ }^{3}$
}

\begin{abstract}
This paper evaluates the effect of the voltage harmonic distortion over the efficiency of a compact fluorescent lamp that is fed with a constant RMS voltage and constant frequency. Several works have been published about the assessment of compact fluorescent lamps, but the effect of the voltage distortion over the efficiency is still an open topic. This work focuses on designing an experiment to estimate the efficiency of a compact fluorescent lamp while changing the voltage harmonic distortion of the power supply. First, a mathematical model that represents a bus susceptible to harmonic distortion (high impedance) that feeds the compact fluorescent lamp is analyzed. Then the mathematical model is reproduced through a test bench in a laboratory of rotating electrical machines. The test bench produces a three-phase bus with constant voltage and frequency, and variable voltage harmonic distortion. The compact fluorescent lamp is subjected to varying harmonic voltage distortion while recording its electrical variables and the produced lumens to estimate its efficiency. That is a practical approach to calculate the lamp efficiency while several
\end{abstract}

\footnotetext{
1 Universidad Nacional de Colombia (Medellín-Antioquia, Colombia). earojas@unal.edu.co. ORCID: 0000-0002$\underline{5385-3328}$

2 Ph. D. Universidad Nacional de Colombia (Medellín-Antioquia, Colombia). ajsaaved@unal.edu.co. ORCID: 0000-0002-2529-5082

${ }^{3}$ Ph. D. Universidad Nacional de Colombia (Medellín-Antioquia, Colombia). caramosp@unal.edu.co. ORCID: $\underline{0000-0003-2231-4177}$
} 
works limit their scope measuring only the efficiency of the input converter. The experimental results show that a variation of the voltage harmonic distortion of $8 \%$ on a compact fluorescent lamp reduces its efficiency. Those results put into evidence the importance of regulating harmonic distortion limits to reduce or prevent the increment of power losses caused by harmonic components.

Keywords: compact fluorescent lamp; efficiency reduction; electrical machine laboratory; harmonic source; voltage harmonic distortion.

\section{Efecto de la distorsión armónica de voltaje en la eficiencia de una lámpara compacta fluorescente}

\section{Resumen}

En este artículo se evalúa el efecto de la distorsión armónica de voltaje sobre la eficiencia de una lámpara fluorescente compacta que es alimentada con un voltaje RMS y una frecuencia constante. Varios trabajos se han publicado acerca de la evaluación de lámparas fluorescentes compactas, pero el efecto de la distorsión de voltaje sobre la eficiencia aún es un tópico abierto. Este trabajo se enfoca en diseñar un experimento para estimar la eficiencia de una lámpara compacta fluorescente mientras cambia la distorsión armónica de voltaje de la fuente de alimentación. Se parte de un modelo matemático que representa un barraje susceptible a la distorsión armónica (alta impedancia) que alimenta la lámpara compacta fluorescente. Luego, el modelo matemático es reproducido a través de un banco de pruebas en un laboratorio de máquinas eléctricas rotativas. El banco de pruebas produce un barraje trifásico con voltaje y frecuencia constantes, y una distorsión armónica de voltaje variable. La lámpara fluorescente compacta es sometida a la variación de la distorsión armónica de voltaje mientras se registran sus variables eléctricas y los lúmenes producidos para estimar su eficiencia. Esta es una aproximación práctica para calcular la eficiencia de la lámpara, mientras que varios trabajos limitan su 
alcance midiendo solamente la eficiencia del convertidor de entrada. Los resultados experimentales muestran que una variación de la distorsión armónica de voltaje del $8 \%$ en una lámpara fluorescente compacta reduce su eficiencia. Estos resultados ponen en evidencia la importancia de reducir los límites de distorsión armónica para reducir o prevenir el incremento de pérdidas de potencia causadas por componentes armónicos.

Palabras clave: distorsión armónica de voltaje; fuente armónica; laboratorio de máquinas eléctricas; lámpara fluorescente compacta; reducción de eficiencia.

\section{Efeito da distorção harmônica de voltagem na eficiência de uma lâmpada compacta fluorescente}

\section{Resumo}

Neste artigo avalia-se o efeito da distorção harmônica de voltagem sobre a eficiência de uma lâmpada fluorescente compacta que é alimentada com uma voltagem RMS e uma frequência constante. Vários trabalhos se têm publicado acerca da avaliação de lâmpadas fluorescentes compactas, mas o efeito da distorção de voltagem sobre a eficiência ainda é um tópico aberto. Este trabalho enfoca-se em desenhar um experimento para estimar a eficiência de uma lâmpada compacta fluorescente enquanto muda a distorção harmônica de voltagem da fonte de alimentação. Parte-se de um modelo matemático que representa uma barragem susceptível à distorção harmônica (alta impedância) que alimenta a lâmpada compacta fluorescente. Depois, o modelo matemático é reproduzido através de um banco de provas em um laboratório de máquinas elétricas rotativas. $\mathrm{O}$ banco de provas produz uma barragem trifásica com voltagem e frequência constantes, e uma distorção harmônica de voltagem variável. A lâmpada fluorescente compacta é submetida à variação da distorção harmônica de voltagem enquanto registram-se suas variáveis elétricas e os lúmenes produzidos para estimar sua eficiência. Esta 
é uma aproximação prática para calcular a eficiência da lâmpada, enquanto que vários trabalhos limitam seu alcance medindo somente a eficiência do conversor de entrada. Os resultados experimentais mostram que uma variação da distorção harmônica de voltagem de 8 \% em uma lâmpada fluorescente compacta reduz sua eficiência. Estes resultados põem em evidência a importância de reduzir os limites de distorção harmônica para reduzir ou prevenir o incremento de perdas de potência causadas por componentes harmônicos.

Palavras chave: Distorção harmônica de voltagem, fonte harmônica, laboratório de máquinas elétricas, redução de eficiência, lâmpada fluorescente compacta. 


\section{INTRODUCTION}

The need to improve the efficiency of energy consumption has been evident in recent decades. Therefore, every discipline is working to improve the processes aimed at improving the energy production and consumption [1-2]. The new developments in technology have increased the electrical energy demand for nonlinear loads, which reduce the power quality of the distribution systems. At the residential level, the nonlinear loads correspond to computers, mobile phones, LED lamps, compact fluorescent lamps (CFLs), etc. Those loads request discontinuous current and therefore deform the voltage waveform of the distribution systems [3].

Academic authorities and researchers developed a workshop on power system harmonics, on January 2014. One of the discussions was about the main issues on harmonics at that time and in the close future. As a result of that workshop, a roadmap was written and published [4]. There is a specific topic in voltage distortion that says: "A reduction in efficiency of end-user equipment was reported in cases with high voltage distortion. This phenomenon should be urgently studied further. If it is shown that this reduction in efficiency is significant, it could form the basis for new voltage-distortion limits."

Based on the last statement, it is inferred that all the nonlinear final user devices that are connected to the distribution systems, should be evaluated to identify the effect of voltage distortion on their efficiency. In this way, determining the effects of the voltage harmonic distortion into the efficiency of electrical loads will make it possible to revise the harmonic distortion limits defined in regulation documents.

In recent years, replacing incandescent bulbs by CFL has been a successful strategy to reduce electrical losses in lighting systems [5]. However, it has been demonstrated that CFL and LED lamps, when massively installed, can introduce a voltage harmonic distortion into the connected bus; for example, a $12 \%$ system load due to CFLs produces a $9.64 \%$ voltage harmonic distortion [6]. That is a good 
example of how nonlinear loads increase the voltage harmonic distortion which could affect the efficiency of the connected loads.

The objective of this paper is to show the effect of the supply voltage harmonic distortion into the efficiency of a nonlinear load, in this case a CFL. First, a single line diagram is used to analyze the power consumed by a CFL while it is fed with a voltage source with a harmonic distortion. The apparent power is calculated following the IEEE Standard Definitions for the Measurement of Electric Power Quantities Under Sinusoidal, Nonsinusoidal, Balanced, or Unbalanced Conditions [7]. Then, an experimental bench formed by a three-phase power source with constant voltage and constant frequency, is used to produce different levels of voltage harmonic distortion. The CFL is powered with the source while changing the voltage harmonic distortion and its efficiency is estimated from the active power demanded by the CFL and its produced lumens.

The rest of the paper is organized as follows: Section 2 presents the methodology used in this work; in particular, it presents the mathematical model used in the experiment design. Section 3 describes the experiment design, reporting the experimental results and the discussion. The conclusion closes the paper.

\section{Methodology}

Figure 1 presents the single line diagram of an electric system formed by a constant voltage source $V_{s}$, an impedance $Z_{s}$, a bus, a nonlinear load requesting discontinuous current, and a target load in which the analysis will be performed. In figure $V_{l o a d}$ is the voltage in the bus where the loads are connected. 
Voltaje source with high impedance

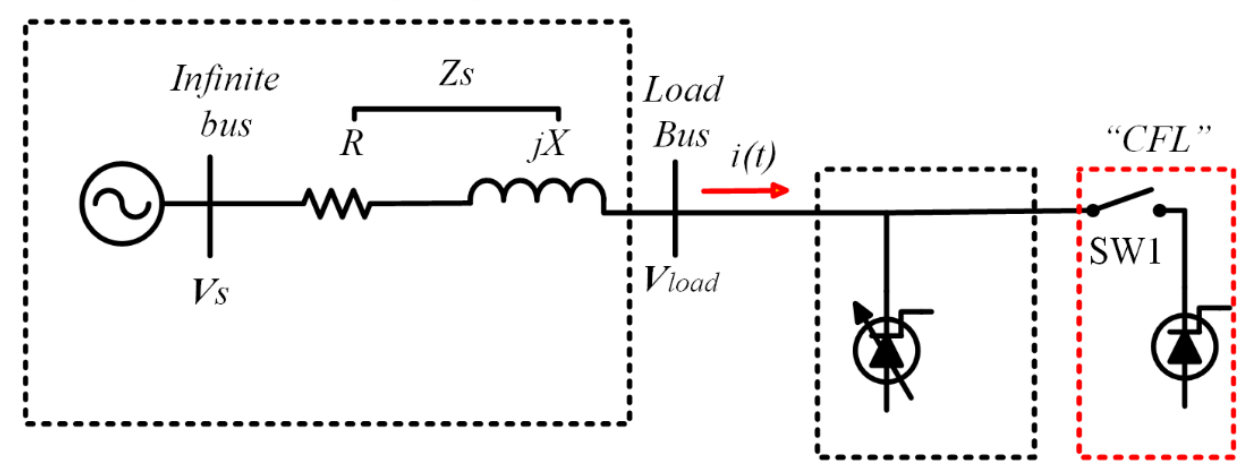

Variable nonlinear load

Fig. 1. Diagram of a bus with constant voltage and variable harmonic content.

Before closing SW1, the nonsinusoidal current $i(t)$ requested by the variable nonlinear load can be divided into the fundamental and harmonic components as it is shown in (1).

$$
i(t)=I_{1} \sin \left(\omega_{1} t+\theta_{1}\right)+\sum_{n=3,5,7 \ldots}^{\infty} I_{n} \sin \left(n \omega_{1} t+\theta_{n}\right)
$$

Where the $I_{1}$ is the magnitude of the fundamental current, $\omega_{1}$ is the fundamental frequency, and $\theta_{1}$ is the phase angle of the fundamental current. Since the load is connected through an impedance $Z_{s}$, the demanded current produces a voltage drop. The bus voltage reflects the fundamental and harmonic components of current over the impedance and therefore the voltage at the load node is given by (2).

$$
V_{\text {load }}=V_{s}-I_{1} Z_{s} \sin \left(\omega_{1} t+\theta_{1}\right)-\left[\sum_{n=3,5,7 \ldots}^{\infty} I_{n} \sin \left(n \omega_{1} t+\theta_{1}\right)(R+j n X)\right]
$$

The two first terms of $V_{\text {load }}$ represent the voltage drop caused by the fundamental component of the load current, while the third term represents the voltage drop caused by the harmonic components of the load current. Therefore, any device connected to the load bus will be supplied by a voltage with harmonic distortion. The difference or total deviation of a distorted waveform from the fundamental component is calculated with a harmonic distortion factor. Equation (3) reports the voltage THD. This factor will be used to indicate the harmonic content in the analyzed voltage. 


$$
T H D_{V}=\frac{V_{r m s H}}{V_{r m s 1}}=\frac{\sqrt{\sum_{n=2}^{h_{m a x}} V_{r m s, n}^{2}}}{V_{r m s 1}}
$$

The apparent power demanded by the load is defined by (4), where both load current and voltage are expanded into their fundamental and harmonic components.

$$
S^{2}=V_{r m s 1}^{2} I_{r m s 1}^{2}+V_{r m s 1}^{2} I_{r m s ~}^{2}+V_{r m s H}^{2} I_{r m s 1}^{2}+V_{r m s H}^{2} I_{r m s H}^{2}
$$

The first term corresponds to the fundamental component, the second term is defined as the power of current distortion, the third term is defined as the power of voltage distortion, and the fourth one is defined as harmonic apparent power. A first hypothesis is that the last three terms exhibit an active power component entering into the load that will not have an effect on the load output, which will reduce the load efficiency.

The system presented in Figure 1 is adequate to show how a current with harmonic content, drawn by a nonlinear load, can produce a voltage in the load bus with harmonic content. The system is also adequate to show that the increment of the load reduces the RMS voltage of the load bus. If a constant RMS voltage is required during the increment of the load, it is necessary to introduce a voltage regulator. The system presented in Figure 1 is implemented in a laboratory of rotating electrical machines. Figure 2 shows the electrical scheme of the experimental bench. The voltage source with high impedance is implemented with a pair of synchronous machines. A synchronous motor (SM) is used as a constant speed driver ensuring a constant frequency in the synchronous generator (SG), and consequently its RMS voltage. Because the RMS voltage of the generator is reduced with the increment of the electric load, the field current of the SG can be adjusted for every load value to keep constant the SG voltage. With this set of synchronous machines, it is possible to produce a bus with a constant RMS voltage facing a variable load.

On the other hand, to produce a variable harmonic content of voltage in the load bus, a variable nonlinear load is connected to the SG, see Figure 2. The nonlinear load 
is implemented with another set of electrical machines. The set is composed by a speed driver feeding an induction motor (IM), which drives a dc generator (DC G). The increment in the voltage distortion in the load bus occurs due to the increment in the nonlinear current of the speed driver, which flows throughout the synchronous impedance of the SG producing harmonic voltage drops as can be seen in the third term of Equation (2). The increment of the current of the IM occurs due to the increment in the load of the DC G. The load of the DC G are incandescent bulbs connected to its terminals. Therefore, connecting incandescent bulbs to the terminals of the DC G will produce an increment in the voltage harmonic content of the load bus.

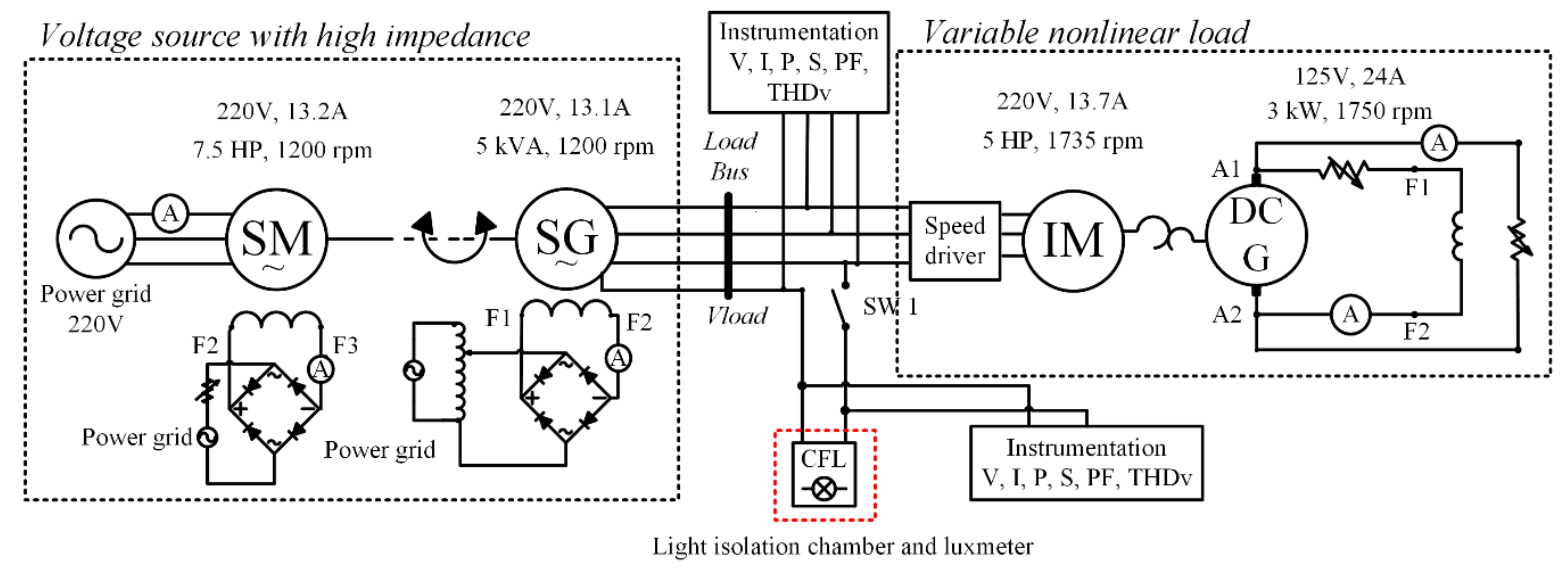

Fig. 2. Electric diagram of the experimental bench.

Figure 3 presents photographs of the test bench built to reproduce the electrical behavior of the system shown in Figure 1. The initial operation conditions of the experiment consist into drive the SM until nominal speed and adjust the excitation field of the generators to reach its nominal voltage. Then, a CFL is connected to a phase of the three-phase bus when the voltage distortion is the lower one achievable with this bus, and this is the condition to measure the first data set. Subsequently, the dc generator is charged increasing the $T H D_{v}$ of the CFL source voltage, and the 
input and output variables of the lamp are registered. A single-phase harmonics analyzer is connected to the CFL terminals, in this case a Fluke 41B. Such analyzer measures and stores the voltage, current, active, reactive, and apparent power, power factor, and voltage total harmonic distortion. Because the CFL output is light, it is measured as luminous flux in Lumen ( $\mathrm{Im})$. During the experiment, the luminous flux of the CFL was measured using the luxmeter TPM LX1010BS. It was necessary to isolate the lamp and the luxmeter into a chamber (cardboard box) to avoid the effect of other light sources on the luxmeter measurement. The efficiency of the lamp is estimated as lumens per watts, i.e. measuring the input power of the lamp in watts (W) and the output luminous flux in lumen (Im). A classical procedure to calculate efficiency as the ratio of output power over input power it is not possible in this type of loads. This process was repeated increasing the dc generator load, and registering the input and output variables of the CFL.

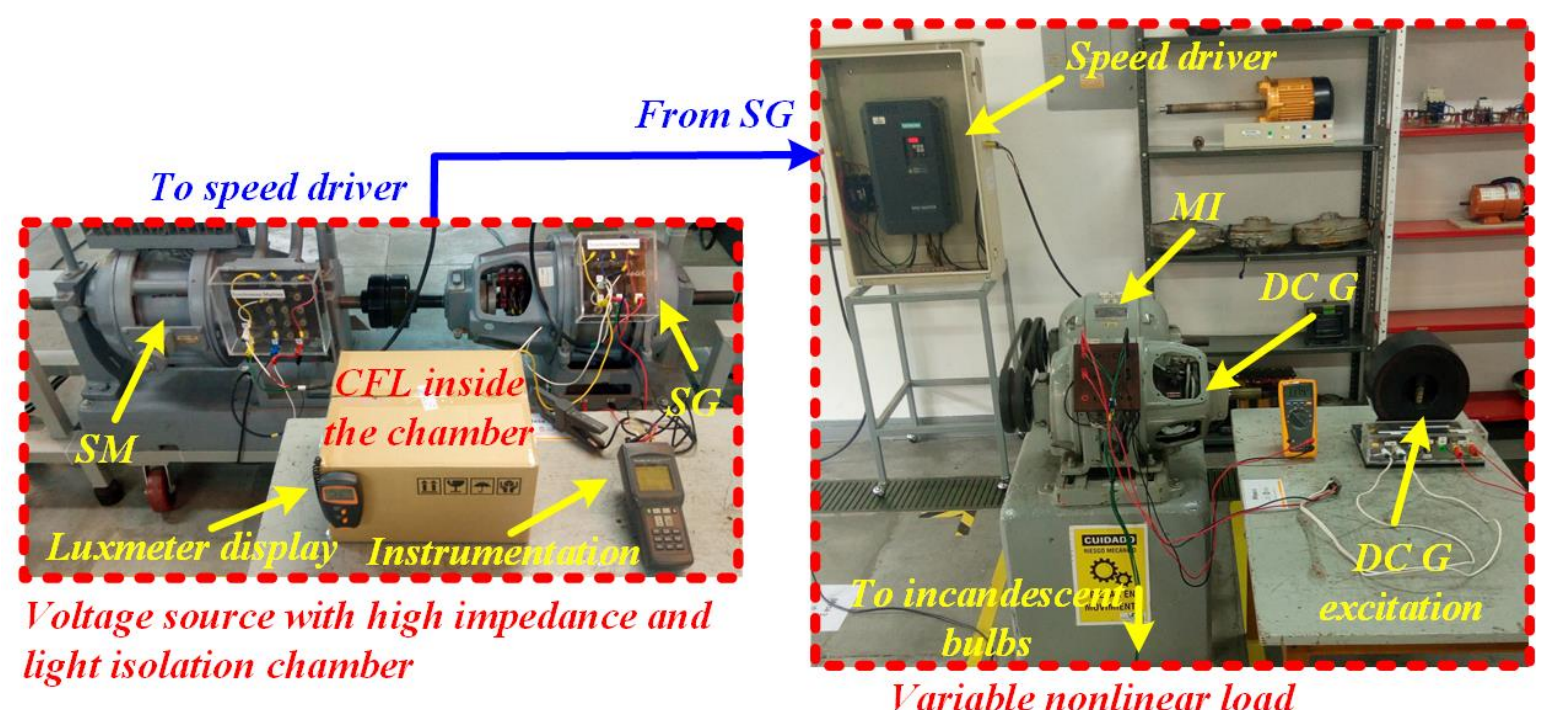

Fig. 3. Experimental bench of a power source with constant rms voltage and variable voltage harmonic content. 


\section{Results AND Discussion}

Figure 4 reports the rms value of the load voltage and its $T H D_{V}$, calculated with (3) in function of the number of incandescent bulbs connected to the dc generator. The $T H D_{V}$ changed from $8.2[\%]$ to $15.3[\%]$ during the experiment. Those results confirm that the $T H D_{V}$ changes while the rms value remains constant. For every load connected to the dc generator, the CFL variables are recorded: current, active power, reactive power, apparent power, power factor and lumens in function of the $T H D_{V}$.
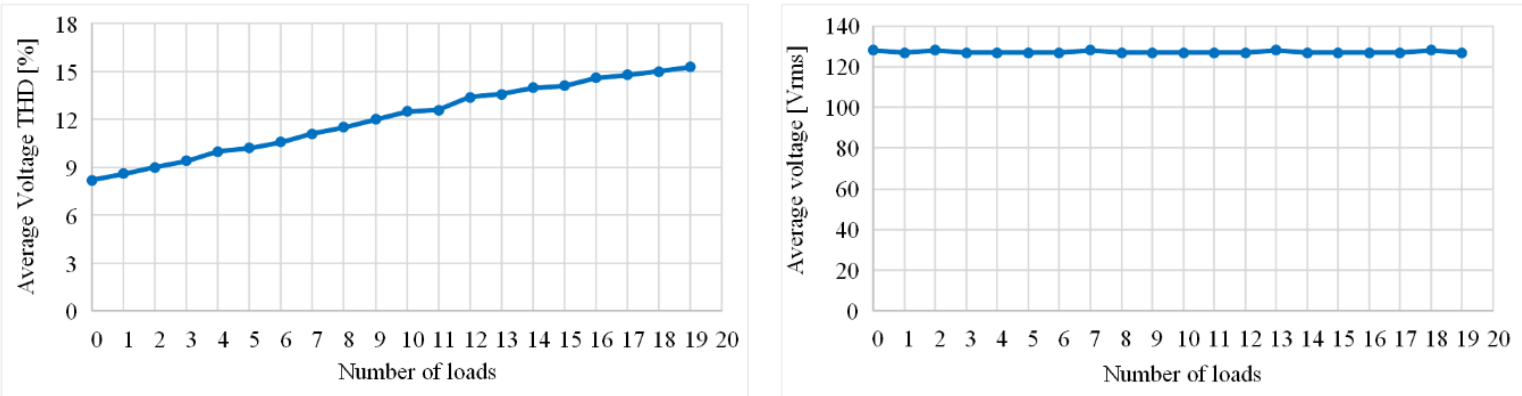

Fig. 4. Variation of the total harmonic distortion of load voltage and its rms value during the experiment.
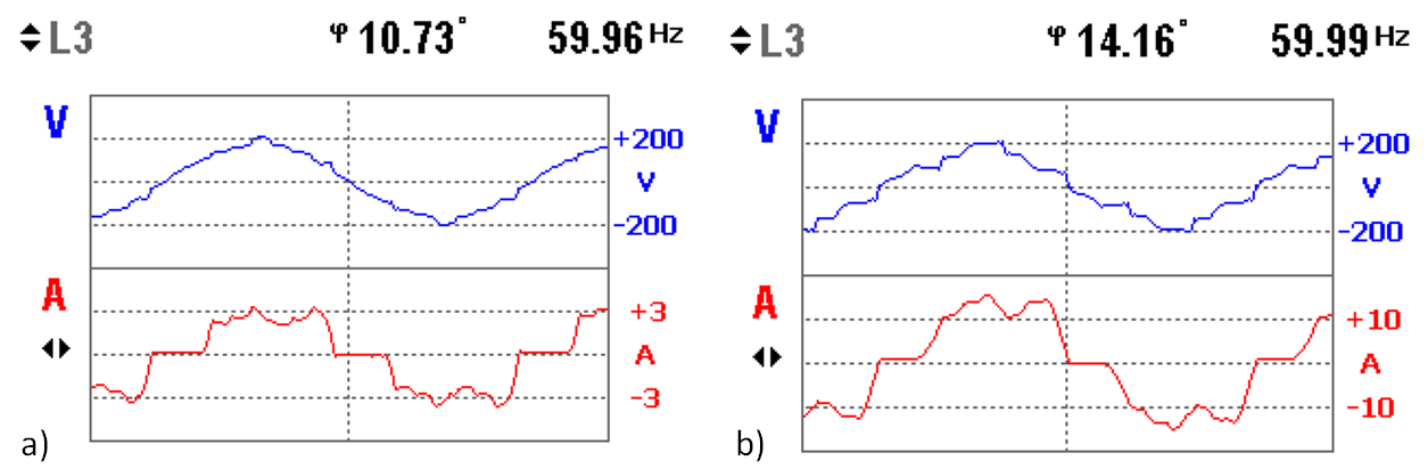

Fig. 5. Waveforms of voltage in the load bus and nonlinear load current. a. Minimun THDv b. Maximun THDv. 
Figure 5 presents the waveforms of the bus voltage and the nonlinear load current registered for two operating conditions of the system. Those waveforms were registered during the characterization of the electrical machine sets as a voltage source with constant RMS value and a variable THDv. Figure 5a was registered when the nonlinear load was recently connected to the SG; while the voltage waveform presented in Figure $5 \mathrm{~b}$ corresponds to the maximum possible current drawn by the nonlinear load. The voltage waveforms presented in Figure 5 have approximately the same magnitude, but the different harmonic content is evident.

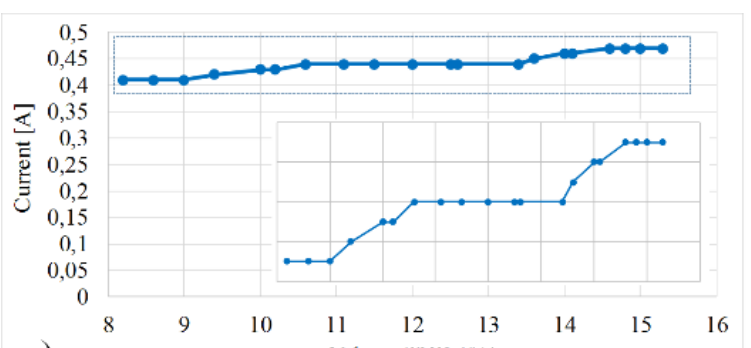

a)

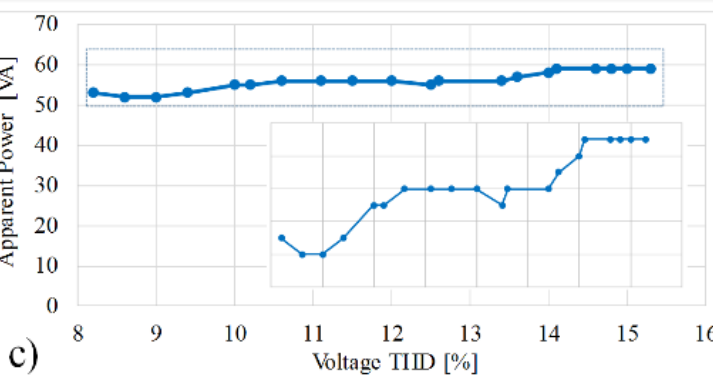

c)

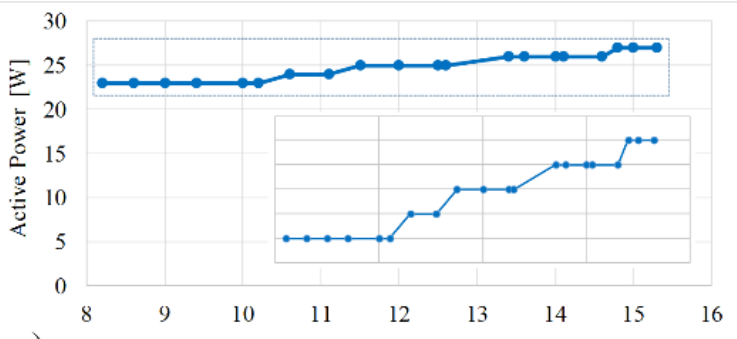

e)

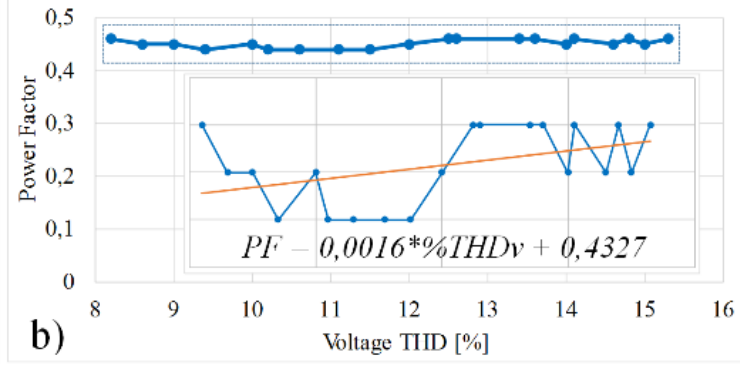

60,0
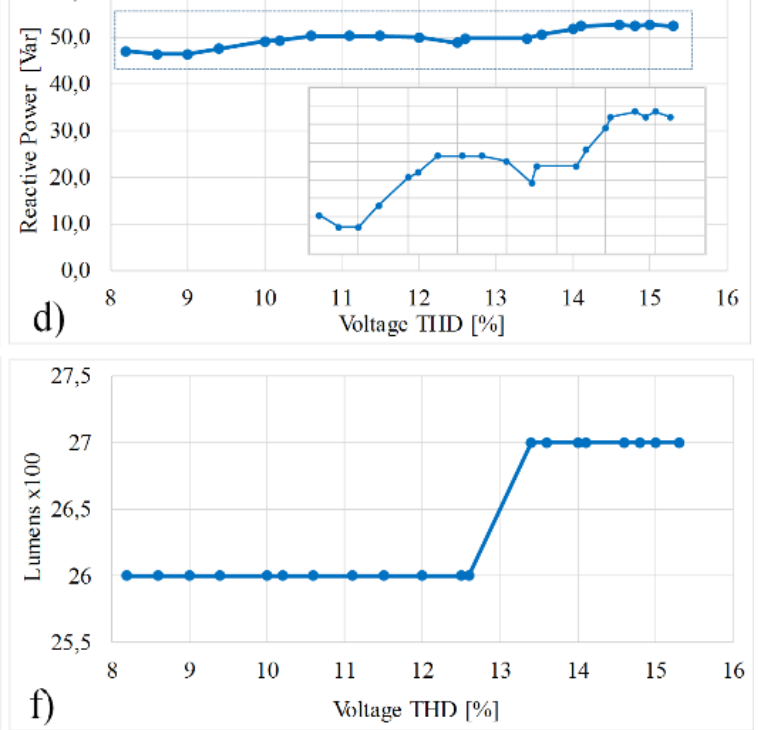

Fig. 6. Results of the experiment that verify the impact of varying the THDV on the efficiency of a residential load. 
Figure 6 presents the behavior of the variables during the experiment. Figure $6 a$ shows the rms current requested by the CFL. The figure reports an increment of the current, while the source voltage is constant, but with increments in the THDV. Those results show a dependency of the current requested by the CFL with respect to the voltage harmonic distortion, but the current increment is nonlinear with respect to the increment of the $T H D_{V}$. The figure shows two current increments: the first one is a current increment from 0.41 to 0.44 A when the $T H D_{V}$ changes from $9 \%$ to $10.6 \%$; the second one is a current increment from 0.44 to $0.47 \mathrm{~A}$ when the $T H D_{V}$ changes from $13.4 \%$ to $14.6 \%$. Figures $6 \mathrm{c}, 6 \mathrm{~d}$ and $6 \mathrm{e}$ report the variation of the apparent, reactive and active powers, respectively, for a variation in $T H D V$. The apparent and reactive powers exhibit a similar variation pattern. During the first six registers the active power does not change, while both apparent and reactive powers change with the same pattern. The reactive power changes from 47.1 to $52.4 \mathrm{Var}$, i.e. an increment of $5.4 \mathrm{Var}$, which corresponds to an increment of $11.25 \%$ of the initial value. Similarly, the apparent power changes from 53 to 59 VA, i.e. an increment of $11.32 \%$; while the active power changes from 23 to $27 \mathrm{~W}$, which corresponds to an increment of $17.39 \%$. The power factor, reported in Figure $6 \mathrm{~b}$, is almost constant around 0.45 inductive for all the experiment. Finally, Figure $6 \mathrm{f}$ reports the change of the lumens produced by the CFL. It is observed that a single change occurs due to the variation of the $T H D_{V}$, which occurs when the $T H D_{V}$ changes from $12.6 \%$ to $13.4 \%$. Instead, the other changes on the $T H D_{V}$ do not produce changes on the CFL lumens. The change on those lumens is from 2600 to $2700 \mathrm{Im}$, i.e. $3.84 \%$.

Contrasting the active power demanded by the CFL with the change of the produced lumens and the variation of the $T H D_{V}$, it is concluded that increments on the $T H D_{V}$ reduced the CFL efficiency. This is observed in the increment of the active power requested without significant increments on the lumens produced by the CFL. 
Therefore, higher $T H D_{V}$ forces the CFL to consume higher power for the same lumens production.

\section{CONCLUSION}

The effect of the voltage harmonic distortion over the efficiency of a CFL has been experimentally evaluated in this paper. The analysis of results shows that increments in the voltage total harmonic distortion, on a CFL, between $8.2 \%$ and $15.3 \%$, and keeping constant both rms voltage and frequency, produce increments in the current, active power, reactive power and apparent power, but the light production remains almost constant. The increment in the input current of the CFL implies an increment in the electrical losses of the final user devices, hence it confirms the efficiency reduction. The results put into evidence the requirement of defining standard tests to evaluate the efficiency of final user devices, and also the need to review the harmonic distortion limits in regulation documents.

\section{AUTHOR's CONTRIBUTION}

Esteban Rojas-Osorio: Data-curation, Formal analysis, Investigation, Resources, Validation, Visualization, Writing - original draft.

Andrés Julián Saavedra-Montes: Conceptualization, Formal analysis, Investigation, Resources, Supervision, Validation, Visualization, Writing - review \& editing.

Carlos Andrés Ramos-Paja: Conceptualization, Investigation, Methodology, Resources, Supervision, Validation, Visualization, Writing - review \& editing.

\section{FOUNDING}

This work was supported by Universidad Nacional de Colombia. Also, Minciencias (Fondo nacional de financiamiento para la ciencia, la tecnología y la innovación 
Esteban Rojas-Osorio; Andrés-Julián Saavedra-Montes; Carlos-Andrés Ramos-Paja

Francisco José de Caldas) was a funding contributor under the project "Estrategia de transformación del sector energético colombiano en el horizonte de 2030 Energetica 2030" - "Generación distribuida de energía eléctrica en Colombia a partir de energía solar y eólica" (Code: 58838, Hermes: 38945).

\section{REFERENCES}

[1] M. Li, D. Patiño-Echeverri, J. Zhang, "Policies to promote energy efficiency and air emissions reductions in China's electric power generation sector during the 11th and 12th five-year plan periods: Achievements, remaining challenges, and opportunities," Energy Policy, vol 125, pp. 429-444, Feb. 2019. https://doi.org/10.1016/j.enpol.2018.10.008

[2] K. S. Sambaiah, T. Jayabarathi, "Loss minimization techniques for optimal operation and planning of distribution systems: A review of different methodologies," International Transactions on Electrical Energy Systems, vol. 30 (2), pp. 1-48, Feb. 2020. https://doi.org/10.1002/2050-7038.12230

[3] A. Nassif, J. Yong, W. Xu, C. Y. Chung, "Indices for comparative assessment of the harmonic effect of different home appliances," International Transactions on Electrical Energy Systems, vol. 23 (5), pp. 638654, Feb. 2012. https://doi.org/10.1002/etep.1620

[4] M. Bollen, J. Meyer, H. Amaris, A. M. Blanco, A. Gil-de-Castro, J. Desmet, M. Klatt, Ł. Kocewiak, S. Rönnberg, K. Yang, "Future work on harmonics - some expert opinions Part I - wind and solar power," in 16th International Conference on Harmonics and Quality of Power, Bucharest, Romania, 2014, pp. 904908. https://doi.org/10.1109/ICHQP.2014.6842870

[5] J. Trifunovic, J. Mikulovic, Z. Djurisic, M. Kostic. "Reductions in electricity losses in the distribution power system in case of the mass use of compact fluorescent lamps," Electric Power Systems Research, vol. 81 (2), pp. 465-477, Feb. 2011. https://doi.org/10.1016/j.epsr.2010.10.004

[6] V. George, A. Bagaria, P. Singh, S. R. Pampattiwar, S. Periwal, "Comparison of CFL and LED lamp harmonic disturbances, economics (cost and power quality) and maximum possible loading in a power system," in International Conference \& Utility Exhibition on Power and Energy Systems: Issues and Prospects for Asia; Pattaya City, Thailand, 2011, pp. 1-5. https://doi.org/10.1109/icuepes.2011.6497742 
Effect of the Harmonic Voltage Distortion on the Efficiency of a Compact Fluorescent Lamp

[7] Institute of Electrical and Electronic Engineers, IEEE Std 1459-2010 IEEE Standard Definitions for the Measurement of Electric Power Quantities Under Sinusoidal, Nonsinusoidal, Balanced, or Unbalanced Conditions, 2010. https://doi.org/10.1109/IEEESTD.2010.5439063 